\title{
The new profile of local managers in the decentralized health system in Brazil
}

\author{
O novo perfil dos gestores locais no sistema de saúde descentralizado \\ no Brasil
}

Sonia Fleury ${ }^{1}$, Assis Luiz Mafort Ouverney²

DOI: 10.1590/0103-1104201811902

1 Fundação Oswaldo Cruz (Fiocruz), Centro de

Estudos Estratégicos (CEE)

- Rio de Janeiro (RJ), Brasil.

Orcid: https://orcid

org/0000-0002-7678-

7642

profsoniafleury@gmail.com

2 Fundação Oswaldo Cruz (Fiocruz), Escola Naciona de Saúde Pública Sergio Arouca (Ensp) - Rio de

Janeiro (RJ), Brasil.

Orcid: https://orcid

org/0000-0002-8581-

3777

assismafort@gmail.com
ABSTRACT This article analyzes the impact of decentralization on the recruiting standards for the position of municipal health secretary, aiming to understand the extent to which local power has been democratized, as a consequence of the Unified Health System (SUS) implementation. Municipal health secretaries all over the country answered a questionnaire at two different times in the decentralization process - 1996 and 2006 - achieving representative results. The goal was to collect data about their socioeconomic, professional profile, political trajectory and public life. Results show that there are more women, brown ('pardos') and low-income people holding the position, and that the qualification of municipal health secretary improved in the period between the two surveys. However, this does not apply to the larger cities and more developed regions, where competition for this position has led to a recruiting standard that combines high levels of professionalism with restricted access for disadvantaged groups. We also found that municipal health secretary are now more politically engaged in manager's associations than in their previous insertion in civil society networks.

KEY WORDS Unified Health System. Decentralization. Local government.

RESUMO Este artigo analisa o impacto da descentralização sobre os padrões de recrutamento para o cargo de secretário municipal de saúde, visando compreender em que medida o poder local tem sido democratizado, como consequência da implementação do Sistema Único de Saúde (SUS). Os secretários municipais de saúde de todo o País responderam a um questionário em dois momentos diferentes no processo de descentralização - 1996 e 2006 - alcançando resultados representativos. O objetivo era coletar dados sobre seu perfil socioeconômico, profissional, trajetória política e vida pública. Os resultados mostram que há mais mulheres, pardos e pessoas de baixa renda que ocupam o cargo, e que a qualificação de secretário municipal de saúde melhorou no período entre as duas pesquisas. No entanto, isso não se aplica às grandes cidades e regiões mais desenvolvidas, onde a competição por essa posição levou a um padrão de recrutamento que combina altos níveis de profissionalismo com acesso restrito para grupos desfavorecidos. Constatamos também que os secretários municipais de saúde estão agora mais envolvidos politicamente nas associações de gestores do que na sua inserção anterior nas redes da sociedade civil.

PALAVRAS-ChaVe Sistema Único de Saúde. Descentralização. Governo local. 


\section{Introduction}

The relationship between democracy and local government is a recurring theme in social sciences, stressing the positive correlation between elected local government, free association, and effective services' provision ${ }^{\mathbf{1 , 2}}$. According to John Stuart Mill, elected local government is more likely to tackle local affairs base on suitable knowledge, skills and expertise $^{3}$. Besides being a barrier against centralism, local scale is the most adequate for ensuring individual needs while preserving diversity. However, since democracy implies the impersonal, competent and non-discriminatory exercise of power as a requirement for expanding citizenship, the predominance of the rational-legal bureaucratic administration, in the development of the modern state, has propelled trends to centralization. This results in inflexible state structures, giving way to contradictory moves of strengthening local self-government. Also expressed as a conflict between public administration and policy, or efficiency versus responsibility.

Dahl ${ }^{4}$ identified three problems regarding public administration science, one of them being the impossibility to ignore the relationships between public administration and social setting, stressing the importance of cultural differences and historical experiences. According to Finner ${ }^{5(335)}$ administrative responsibility "is not less important to democratic government than administrative efficiency; it is even a contributor to efficiency in the long run". His debate with Friedrisch was about whether responsibility is a subjective notion associated to official's intellectual integrity and loyalty or depends on the existence of an appropriate sanctions and rewards arrangement. Currently, it is argued that public administration in a democracy is different from private management because it must go beyond efficiency and incorporate other criteria as legitimacy, representativeness and leadership. Instead of expelling normative values from public administration, it is argued that the government must create value for society ${ }^{6-8}$.
State and society have undergone transformations characterized by growing differentiation and complexity of the social process, requiring new forms of coordination, that go beyond the existing ones: state-centered coordination that is centralized and hierarchical; and market-centered coordination that is fragmented, horizontal and private ${ }^{9}$. Therefore, political de-concentration has been defended for ensuring a greater degree of autonomy in the exercise of local power, with a resulting increase in accountability, network of actors and citizen participation ${ }^{\mathbf{1 0}}$.

Recent academic debate in public administration introduced new perspectives that go beyond the polarized discussion between the New Public Management (NPM), which has introduced the principles of competitive performance and consumer choice, and the traditional public administration, emphasizing bureaucratic control in decision-making process. They highlight the new roles of local governments in a more complex setting. However, both traditional public administration and NPM principals and tools are still applied in conjunction with new governance approaches in a not entirely coherent reform design ${ }^{8}$.

The local governance perspective emphasizes the State capacity to steer and promote collective action (Local Governance), to stimulate participation (Netwok Governance) to enhance diversity (Governance of Diversity), and to create public value $3,6-8,11$.

By enhancing citizenship and participation, local government allows society learning trough communicational instruments and public arenas for consensus building. According to Stoker ${ }^{8}$, accountability thus relies on a complex and continuous exchange among leadership and checks and balances. Our study focus on the leadership profile as both, a product and a propeller, of this changing context in democratic and decentralized settings.

In Brazil, during the transition to democracy the demand for social inclusion was associated to claims of independent local governments and the renewal of the ruling elite. The intense 
process of decentralization has allowed different local interest groups to fight over designing the public agenda in participatory institutions and consensus building processes, enrolling national and regional players ${ }^{\mathbf{1 2}}$. The challenge has been to build a cooperative federative model, enabling autonomous local governments and society to exercise local power, but compatibly with the role of the central government to coordinate policies and implement distributive mechanisms. Those are indispensable in such a large nation with major regional differences and huge social gaps.

Healthcare system was pioneer in creating a decentralized management and cooperative coordination model for the subnational units. Numerous studies pointed to contradictory results of decentralization as the strengthening of local democracies and the financial and institutional weaknesses of local governments. Erratic efforts to manage locally social policies ${ }^{\mathbf{1 3}-15}$ are attributed to the local dependence on central government funds. The recentralization of the decision-making process has increased the diffusion of innovations in healthcare programs ${ }^{\mathbf{1 6}, 17}$.

Regarding the participative processes and institution, studies show a strengthening democracy at the local and regional levels, where co-management different interest groups to participate in healthcare policies ${ }^{\mathbf{1 8}, 19}$. These studies point to the following virtues: (i) the existence of formal decision-making arenas where conflicts are publicly transacted; (ii) the development of a more aware citizenry that is better able to interfere in public management; (iii) the enlargement of public arena with social players organized into powerful political communities. However, they highlight institutional and political weakness of participation due to the lack of technical and political skills required for the effective exercise of social control.

This article looks at the relationship between democratization and decentralization from another angle, one that addresses the renewal of the political authorities. We consider municipal health secretary as local political elites in charge of an important public function. By looking at the changes in the managers profiles at two different points within a ten-year period, we were able to pick up how decentralization changed the conditions for access to this position.

Although the data are limited to the 19962006 decade, the importance of this article is justified by three reasons: (1) lack of national studies on the profile of managers, since most of the studies are of local scope; (2) greater range of aspects analyzed, including variables of origin and political trajectory, transcending studies that focus only on training and management skills; (3) the originality of the model created specifically for this research allows us to go beyond the description of the profiles and to study different patterns of recruitment. Thus, the possible temporal deficiencies can be attenuated by means of comparisons with more recent studies on other public managers. Moreover, the relevance of this study is proven by the fact that it is being used in ongoing studies sponsored by Conasems ${ }^{20}$.

Results display important changes towards a more diverse and professional profile for local managers, showing that conservative recruiting standards have been replaced by a more equalitarian and meritocratic access. However, we find that in large cities, where there is more competition, access to the position of municipal health secretary tends to be elitist, maintaining a more homogeneous and traditional recruiting pattern.

\section{Analysis framework: local government and recruiting standards}

This survey aimed to know who the city healthcare managers are and which changes occurred in how they were recruited in 1996 and 2006. We looked for changes in manager profiles during this decade as part of the 
decentralization process underway. As a political-institutional process, decentralization both influences and is influenced by other similar and concomitant processes. Thus, the influence of decentralization on the institutional political dynamics of intergovernmental relations can not be denied. In this period the decentralization process became more intense, characterized by: (i) strengthening local administrations and increasing managerial autonomy; (ii) creating and strengthening consensus building mechanisms involving national, regional and local authorities in the definition and implementation of healthcare policies; (iii) introducing important financial subsidies that led local governments to adopt new care programs fostered by the federal government $\mathbf{1 4}^{\mathbf{4} 21,22}$. This changed health power structure and affected the federative system, leading to a more democratic arrangement of governability and governance.

In different countries studies pointed to the increasing gap between the scarcity of resources and the growing responsibilities of local authorities ${ }^{\mathbf{1 0}, 23}$. This conflict is not different in Brazil. However, we want to highlight the importance of professionalism as a requirement for increasing local government responsibility, even knowing how controversy this subject is in public administration field ${ }^{\mathbf{2 4}}$. Decentralization of the healthcare system is closely linked to the democratization process for two reasons: (a) it would strengthen the sub-national powers and the federative pact, and (b) it would expand access and thus ensure the universal right to healthcare ${ }^{25}$. Besides, a critical element of democracy is to expand the access of different groups in society to the exercise of power as the ruling elite of local government. This latest articulation between decentralization and democracy was neither a goal in the Unified Health System (SUS) design and nor subject of academic research.

Our hypothesis was that decentralization would lead to enlarge diversity among managers as it streghtens the democratic acess to the governing elite. Nevertheless, it was important to check if democratization came or did not came with an increase in professional management skills, enabling municipal health secretaries to perform effectively.

The municipal health secretaries are the health authorities in charge of managing local healthcare systems in Brazilian cities and towns. They are part of the local government, being selected by the elected mayors. They can be recruited from within or outside the ranks of public administration, as part of the political arrangement that ensures local government fulfills the conditions of legitimacy and governance. However, they have to satisfy technical requirements since their responsibilities have increased as part of the process to decentralize social policies, stipulated in the 1988 Brazilian Constitution.

According to health legislation, municipal health secretaries are important political players, as they have the legal and managerial responsibility for healthcare provision, and management of financial resources. They are represented in all levels of health policy decision-making process ${ }^{26}$, such as the Regional Bipartite Inter-managers Committees - RBIC, the National Tripartisan Inter-managers Committee - NTIC (RBIC are peer negotiation and decision making bodies that exist in each state, where local and regional managers set healthcare policy. These and the Ministry of Health meet in the NTIC to make decisions at the national level) and at the participatory arenas as health councils and conferences. They are also strongly organized in corporative associations, regionally (State Council of Municipal Health Secretariats Cosems) and nationally (National Council of Municipal Health Secretariats - Conasems). Consequently, they have significant political articulation and capacity to influence almost all national and regional healthcare policy strategies. They also influence the legislative and political party agendas, and create alliances with actors in other areas of public policy and citizenship defense.

As an important locus for exercising 
government power the position of municipal health secretary is a dynamic space for political competition among the local elites, and an important element in the configuration of local power structure. Personal and professional characteristics and political trajectories of municipal health secretaries provide subsidies to analyze how local government is sensitive to social transformation.

That being the case, it was expected that the SUS decentralization would have encouraged a breach with the old-style political array, characterized as a patronage pattern, since the oligarchic elite monopolize local power. Diversifying the managers' profile suggests a positive relationship between decentralization and power democratization at the local level.

Democratization of local power allows people from disadvantage groups (women, afro and indigenous descendants and nonmedical professionals in different areas) to have an equal opportunity to exercise local power as managers in healthcare system. This way, access to this position of the local political elite is subject to the capabilities demonstrated in the individual's political and professional life, and should be free of any sponsorship by family members or allies.

Democratic access enables renewing local elites, whereas conservative or elitist recruiting standards perpetuate the ruling elites. Democratization can however, take place with no increase in professionalization, which would be an inefficient model of social renewal, as it would do nothing to enhance the qualifications of local managers. Another case is when the increase in qualifications is not followed by access democratization. In other words, an elitist model occurs when the same groups with the greater resources stay in power (for example white men, physicians, etc.), even though expertise is required (chart 1).

Chart 1. Standards of recruiting and access to local power

\begin{tabular}{lll}
\hline & Less access & More access \\
\hline Less qualified & Conservative & Inefficient \\
& Limited professionalization and renewal & Renewal with no professionalization \\
\multirow{3}{*}{ More qualified } & Elitist & Democratic \\
& Meritocratic and elitist - Professionalization & Renewal of the elites Professional management \\
& without renewal & \\
\hline
\end{tabular}

Source: Own elaboration.

If we cross the variable access to the position with the variable level of qualification, we find four recruiting models that will have different social impact:

The conservative model, where recruiting is such as to perpetuate the oligarchies in power with limited professionalization;

The inefficient standard where ease of access does not come with increased professionalization;

The elitist model that is meritocratic and based on high levels of professionalism, albeit with access limitations, and

The democratic standard that combines easier access to different social and professional groups with increasingly professional skills. 


\section{Research methods}

The data analyzed in this study was collected using a questionnaire posted to the municipal health secretaries, and also distributed at events organized by Conasems. We grouped the questions into four blocks: (1) socioeconomic profile, (2) professional profile; (3) political trajectory and public life; and, (4) municipal health secretary relationship with the position.

Under 'socioeconomic' profile, we looked for information on social origin, current occupational status and personal characteristics. Social origin focused on birthplace, parents' education, and family links in the city where the position of municipal health secretary is hold, and whether or not the secretary belongs to higher socioeconomic stratum. To determine geographic mobility and socio-economic engagement we analyzed how long these individuals lived where, income and prior occupations. Personal characteristics (age, gender, race and marital status) were relevant to measure the diversity of manager profiles.

Under 'professional profile', we analyzed municipal health secretary qualifications and professional trajectory, focusing on degrees and area of professional training, also considering expertise acquired through specific courses to qualify him or her for the position of municipal health secretary, given the new demands of the decentralization process. Under professional trajectory, we analyzed their technical experience and background in public sector management, more specifically in health related areas. We investigated if the municipal health secretary had other employment links and income source in public or private sector.

In 'political trajectory and public life', we focused on their political/electoral experience, political engagement in the healthcare sector and involvement in civil society associations. This data allowed us to analyze changing political governance in the healthcare sector. The new and more complex roles of municipal health secretary demand more professionalization with a greater focus on health management but democratic governance requires close relationship with party players and civil society, lest the position become bureaucratically insulated. We asked about political/ electoral experience, party membership and experience as a political candidate. We also collected data on the political involvement of municipal health secretary in health events and in civil associations.

Regarding their 'relationship to the position', the aim was to learn about stability in the position, the reasons for being appointed and accepting the position, and individual expectations regarding future professional development. We want to know if the decentralization is reducing turnover in this position and the extent to which the reasons to be designated and accept the position are related to professional attributes such as leadership and technical experience, among others.

Questionnaires were applied in 1996 and in 2006. On both occasions, they were distributed to all municipalities in Brazil. The managers answering the questionnaire in 2006 were not the same as those answering the first one in 1996, which is not a limitation as the goal is to analyze the position of municipal health secretary. Statistical analyses during the data collection phase assured the representativeness of the sample but in 2006 we must went back into the field to fulfill accurately the requirement regarding cities with over 500,000 inhabitants. Sample study concluded that the results of the research are representative for the population of the respondent municipalities, and there may be sampling bias for the national level. However, for municipalities with more than 400 thousand inhabitants there is no such risk because a census was carried out ${ }^{27}$.

Table 1 shows that in 1996, the nationwide return was $28 \%$, ranging from $15.3 \%$ in the Northeast to $40.5 \%$ in the South, and between $25.4 \%$ for cities with $0-5,000$ inhabitants to $44.6 \%$ for cities with over 200,000 inhabitants (table 1). 
Table 1. Distribution of questionnaire responses by region` and city population (in thousand inhabitants), 1996 and 2006.

\begin{tabular}{|c|c|c|c|c|c|c|c|c|c|c|}
\hline \multirow{2}{*}{1996} & \multicolumn{8}{|c|}{ Region } & \multicolumn{2}{|c|}{ Population } \\
\hline & $\mathbf{N}$ & NE & MW & SE & $\mathrm{S}$ & $<5$ & $5 \mid 20$ & $20 \mid 50$ & $50 \mid 200$ & $>200$ \\
\hline Number of cities & 398 & 1,558 & 426 & 1,533 & 1,058 & 1,067 & 2,544 & 903 & 376 & 83 \\
\hline Number of respondents & 78 & 238 & 114 & 563 & 429 & 271 & 661 & 300 & 153 & 37 \\
\hline$\%$ of response & 19.6 & 15.3 & 26.8 & 36.7 & 40.5 & 25.4 & 26.0 & 33.2 & 40.7 & 44.6 \\
\hline \multirow[t]{2}{*}{2006} & \multicolumn{8}{|c|}{ Region } & \multicolumn{2}{|c|}{ Population } \\
\hline & $\mathbf{N}$ & NE & MW & SE & $\mathrm{S}$ & $<5$ & $5 \mid 20$ & $20 \mid 50$ & $50 \mid 200$ & $>200$ \\
\hline Number of cities & 449 & 1,793 & 465 & 1,668 & 1,188 & 2,672 & 1,298 & 1,026 & 443 & 124 \\
\hline Number of respondents & 43 & 251 & 90 & 420 & 279 & 440 & 232 & 208 & 126 & 77 \\
\hline$\%$ of response & 9.6 & 14.0 & 19.4 & 25.2 & 23.5 & 16.5 & 17.9 & 20.3 & 28.4 & 62.1 \\
\hline
\end{tabular}

Source: Own elaboration.

MW = Midwestern, N = North, NE = Northeast, $S=$ South, SE = Southeast.

*The South and Southeast have the higher per capita income and socioeconomic development. They are the more dynamic economic hubs in the country.

In 2006, nation-wide return on the questionnaire was smaller (19.5\%), ranging between $9.6 \%$ in the North and $25.2 \%$ in the Southeast, and varies from $17.9 \%$ for cities with fewer than 5,000 inhabitants to $62.1 \%$ for cities with over 200,000 inhabitants.

In both cases, data was organized by region and city population to enable comparisons that would help us to understand the impact of the size of city and regional development level on the profile of the municipal health secretary.

\section{Findings and discussion}

\section{Socioeconomic profile}

At the national level, as shown in chart 2, access to the position of municipal health secretary has been more permeable to managers from outside the city where they perform their tasks, but who have been residing there for over 10 years. In general, their parents had at most a primary education. Most of these managers receive up to $\mathrm{R} \$$ 3,000,00 (values in current $\mathrm{R} \$, 2006$ ) monthly, and have an additional source of income.

Chart 2. Summary of socioeconomic data on municipal health secretaries: social origin, current situation and personal characteristics, $1996 / 2006$.

\begin{tabular}{|c|c|c|c|c|c|c|}
\hline \multirow[t]{2}{*}{ Attribute } & \multirow[t]{2}{*}{ Variable } & \multirow[t]{2}{*}{ Trend (2006) } & \multirow{2}{*}{$\begin{array}{l}\text { Nationwide } \\
\text { variation, } \\
1996 / 2006\end{array}$} & \multicolumn{3}{|c|}{ Variation by region and size (2006) } \\
\hline & & & & Region & & Size \\
\hline \multirow[t]{2}{*}{$\begin{array}{l}\text { Social } \\
\text { origin }\end{array}$} & City of origin & $\begin{array}{l}\text { Managers born } \\
\text { in a different city } \\
(64.3 \%)\end{array}$ & $\begin{array}{l}\text { Slight reduction } \\
(-3.2 \%)\end{array}$ & $\begin{array}{l}\text { More } \\
\text { N (71.7\%) and } \\
\text { MW (74\%) }\end{array}$ & Less & $\begin{array}{l}\text { Less intense }(60.6 \%) \text { in cities with over } \\
200,000 \text { inhabitants }\end{array}$ \\
\hline & $\begin{array}{l}\text { Education of } \\
\text { Father/Mother }\end{array}$ & $\begin{array}{l}\text { Parents with pri- } \\
\text { mary education } \\
\text { only }(66.4 \%)\end{array}$ & $\begin{array}{l}\text { Slight reduction } \\
(-2.5 \%)\end{array}$ & $\begin{array}{l}N(77.7 \%) \text { and } S \\
(70.2)\end{array}$ & & $\begin{array}{l}\text { Increasing percent of parents with more } \\
\text { than a primary education: } \\
31.9 \% \text { ( } 0-5 \text { thousand inhabitants) to } \\
49.2 \% \text { (> } 200 \text { thousand inhabitants) }\end{array}$ \\
\hline $\begin{array}{l}\text { Current } \\
\text { situation }\end{array}$ & $\begin{array}{l}\text { City of resi- } \\
\text { dence }\end{array}$ & $\begin{array}{l}\text { Managers residing } \\
\text { in the city where } \\
\text { they work }(82.5 \%)\end{array}$ & $\begin{array}{l}\text { No change } \\
(+0.4 \%)\end{array}$ & $\begin{array}{l}\text { N (97.3\%) and } \\
\text { MW (95.5\%) }\end{array}$ & $\begin{array}{l}\text { NE } \\
(69.0 \%)\end{array}$ & No significant change \\
\hline
\end{tabular}




\begin{tabular}{|c|c|c|c|c|c|c|}
\hline \multicolumn{7}{|c|}{ Chart 2. (cont.) } \\
\hline \multirow[t]{3}{*}{$\begin{array}{l}\text { Current } \\
\text { situation }\end{array}$} & $\begin{array}{l}\text { Time residing } \\
\text { in city }\end{array}$ & $\begin{array}{l}\text { Managers living } \\
\text { in city where they } \\
\text { work for over } 10 \\
\text { years }(74.5 \%)\end{array}$ & $\begin{array}{l}\text { Slight increase } \\
(+4.7 \%)\end{array}$ & S (81.3\%) & - & $\begin{array}{l}\text { Increases with city size: } \\
74.4 \%(0-5 \text { thousand inhabitants) to } \\
82.6 \% \text { (> } 200 \text { thousand inhabitants) }\end{array}$ \\
\hline & Monthly wage & $\begin{array}{l}\text { Managers making } \\
\mathrm{R} \$ 3.000,00 \text { or } \\
\text { less }(79.3 \%)\end{array}$ & $\begin{array}{l}\text { Slight increase } \\
(+1.8 \%)\end{array}$ & N (89.1\%) & S (78.1\%) & $\begin{array}{l}\text { Decreases with city size: } \\
94.1 \% \text { (0-5 thousand inhabitants) to } 1.6 \% \\
\text { (> } 200 \text { thousand inhabitants) }\end{array}$ \\
\hline & $\begin{array}{l}\text { Other sources } \\
\text { of income }\end{array}$ & $\begin{array}{l}59.3 \% \text { have an- } \\
\text { other source of } \\
\text { income }\end{array}$ & $\begin{array}{l}\text { Significant reduc- } \\
\text { tion }(-15.2 \%)\end{array}$ & NE (66.1\%) & $\begin{array}{l}S \\
(48.3 \%)\end{array}$ & $\begin{array}{l}\text { Increases with city size: } \\
47.4 \% \text { ( } 0-5 \text { thousand inhabitants) to } 67.1 \% \\
\text { (> 200thousand inhabitants ) }\end{array}$ \\
\hline \multirow[t]{4}{*}{$\begin{array}{l}\text { Personal } \\
\text { character- } \\
\text { istics }\end{array}$} & Age & $\begin{array}{l}\text { Managers between } \\
\text { the ages of } 30 \text { and } \\
50(64.9 \%)\end{array}$ & $\begin{array}{l}\text { Slight reduction } \\
(-3.5 \%)\end{array}$ & $N(76.9 \%)$ & SE (59\%) & $\begin{array}{l}\text { Decreases with city size: } \\
\text { Between } 30 \text { and } 50 \text { years of age } \\
47.4 \% \text { ( } 0-5 \text { thousand inhabitants) to } 67.1 \% \\
\text { (> } 200 \text { thousand inhabitants) } \\
\text { Increases with city size: } \\
\text { Between } 50 \text { and } 60 \text { years of age } \\
11.7 \% \text { ( } 0-5 \text { thousand inhabitants ) to } \\
46.8 \% \text { (> } 200 \text { thousand inhabitants) }\end{array}$ \\
\hline & Gender & $\begin{array}{l}\text { Balanced: } 50.1 \% \\
\text { men and } 49.2 \% \\
\text { women }\end{array}$ & $\begin{array}{l}\text { Significant increase } \\
\text { in the number of } \\
\text { women }(+10.4 \%)\end{array}$ & N (58.6\%) & $\begin{array}{l}\text { SE } \\
(45.6 \%)\end{array}$ & $\begin{array}{l}\text { More women in smaller cities } \\
49.2 \% \text { ( } 0-5 \text { thousand inhabitants) to } \\
25.2 \% \text { (> } 200 \text { thousand inhabitants) }\end{array}$ \\
\hline & Race & $\begin{array}{l}\text { Caucasian }(69.3 \%) \\
\text { or mulatto } \\
(26.4 \%)\end{array}$ & $\begin{array}{l}\text { Fewer caucasians } \\
(-14.9 \%) \text { and } \\
\text { more mulattoes } \\
(+14.9 \%)\end{array}$ & $\begin{array}{l}N(64.9 \%) \text { and } \\
N E(41.6 \%)\end{array}$ & $\begin{array}{l}S(7.2 \%) \\
\text { and SE } \\
(13.8 \%)\end{array}$ & $\begin{array}{l}\text { The percent mulattoes decreases with city } \\
\text { size: } \\
\text { Approximately } 27 \% \text { ( } 0-5 \text { thousand inhab- } \\
\text { itants) } \\
18.4 \% \text { ( } 50-200 \text { thousand inhabitants) } \\
9.4 \% \text { (> } 200 \text { thousand inhabitants) }\end{array}$ \\
\hline & Marital status & $\begin{array}{l}74.6 \% \text { are married } \\
\text { or in a stable do- } \\
\text { mestic partnership }\end{array}$ & $\begin{array}{l}\text { Slight reduction } \\
(-2.7 \%)\end{array}$ & MW (82.5\%) & $\begin{array}{l}\mathrm{NE} \\
(69.9 \%)\end{array}$ & $\begin{array}{l}\text { Increases with city size: } \\
\text { Approximately } 74 \% \text { ( } 0-5 \text { th. inhab.) } \\
80.2 \% \text { ( } 50-200 \text { th. inhab.) } \\
88.2 \% \text { (> } 200 \text { th. inhab.) }\end{array}$ \\
\hline
\end{tabular}

Source: Own elaboration.

MW = Midwestern, $N=$ North, $N E=$ Northeast, $\mathrm{S}=$ South, $\mathrm{SE}=$ Southeast.

The majority are between 30 and 50 years of age, are Caucasian or brown and are married or in a stable relationship, as shown in chart 2. Both genders are equally represented. There was a few significant changes in this standard between 1996 and 2006, among which we point to the increase in the number of women $(+10.4 \%)$ and brown $(+14.9 \%)$ in the local management elite. Recent researches shows that the presence of brown in high level careers in the federal administration is much lower, what suggests that decentralization has increased the possibilities for inclusion of socially disadvantaged groups ${ }^{28}$. Comparisons with contemporary and more recent studies on the profile of local public managers show the intensity of the health sector changes that occurred in the analyzed period. The proportion of women in the health sector is much higher than in the mayoral position (11.9\%) in $2017^{29}$ and slightly lower than that found among local education managers in $(68 \%)^{30}$, considering that education is predominantly characterized by female presence. Comparisons regarding race/ethnicity were not possible, as the studies cited did not address this aspect.

We observed that the access to the local managing elite in the SUS is the result of a process of social climbing, geographic mobility, local community engagement and increased diversity regarding personal characteristics. Therefore, the recruitment it is placed further from the 
conservative model of access to local government healthcare elite, characterized particularly by being male, white and the sons of the local elite.

The SUS managers elite was not recruited based primarily on relationships with any local political, economic or corporate group. Likewise, we find that many of these managers come from families with relatively little education, and are the product of growing social mobility. It is also fair to state that, while the majority of the management elite that emerged during the decentralization of the SUS is from outside the cities where they work, they have quite a bit of knowledge of the main problems faced by the local community, having resided in the city for 10 years or more.

By moving away from the conservative recruiting standard in terms of social origin and personal characteristics, the dynamics of renewing local health authorities is showing that decentralization can produce a range of democratizing impacts.

However, democratization has not been uniform across the country, and in fact is quite uneven in terms of region and size of city. We call particular attention to the differences in the proportion of brown and women in the composition of local management elites. We found more women in the poorer regions of the North (58.6\%) and Northeast (54.9\%), compared to the
Southeast (45.6\%). The North and Northeast also had the largest percentages of brown (64.9\% and $41.6 \%$ respectively), while in the more developed regions, South and Southeast, brown held only $7.2 \%$ and $13.8 \%$ of municipal health secretary positions respectively.

We also found large differences in recruiting standards based on city size, with women making up $53.7 \%$ of the municipal health secretary in cities with 5,000 to 20,000 inhabitants, to $25.2 \%$ in cities with over 200,000 inhabitants. The difference is even greater when we look at the percent brown holding the position of municipal health secretary, going from $27.5 \%$ in the smaller cities to $9.4 \%$ in the larger ones. Thus the data reveals that there is greater diversification of municipal health secretary in the less developed regions of the country, and in the poorer cities and towns, with access more limited in the larger cities and wealthier regions.

\section{Professional profile}

As shown in chart 3, most (67.3\%) SUS managers have at least a university degree and are trained in health sciences $(44.9 \%, 11.2 \%$ are MDs), the humanities or business (20.3\%). Most (67.6\%) have taken specific courses to qualify them for the position, especially in public health and planning (39.7\% and $25.6 \%$ respectively).

Chart 3. Summary of municipal health secretaries professional profiles: qualification and professional trajectory, 1996/2006.

\begin{tabular}{|c|c|c|c|c|c|}
\hline \multirow[t]{2}{*}{ Variable } & \multirow[t]{2}{*}{ Trend (2006) } & \multirow{2}{*}{$\begin{array}{l}\text { Nationwide variation, } \\
1996 / 2006\end{array}$} & \multicolumn{3}{|c|}{ Variation by region and size (2006) } \\
\hline & & & Region & & Size \\
\hline $\begin{array}{l}\text { Education/ } \\
\text { University } \\
\text { degree }\end{array}$ & $\begin{array}{l}\text { At least an undergraduate } \\
\text { degree }(67.3 \%)\end{array}$ & Reduction (-5.7\%) & MORE & $\begin{array}{l}\text { LESS } \\
\text { N (50.1\%) and } \\
\text { MW (60.3\%) }\end{array}$ & $\begin{array}{l}\text { Qualification goes up with city size: } \\
49.9 \% \text { (0-5 thousand inhabitants) to } \\
96 \% \text { (> } 200 \text { thousand inhabitants) }\end{array}$ \\
\hline $\begin{array}{l}\text { Professional } \\
\text { education }\end{array}$ & $\begin{array}{l}\text { Secretaries with degrees in } \\
\text { healthcare }(44.9 \%, 11.2 \% \\
\text { have MDs), the humanities } \\
\text { or business }(20.3 \%)\end{array}$ & $\begin{array}{l}\text { significant reduction } \\
\text { in \# of physicians } \\
(-20 \%)\end{array}$ & $\begin{array}{l}\text { Healthcare areas } \\
\text { NE }(52.8 \%) \\
\text { Physicians SE } \\
(14.8 \%)\end{array}$ & $\begin{array}{l}\text { Healthcare ar- } \\
\text { eas S (33.9\%) } \\
\text { Physicians N } \\
(5.8 \%)\end{array}$ & $\begin{array}{l}\text { Training in healthcare increases with } \\
\text { city size: } \\
33 \% \text { ( } 0-5 \text { thousand inhabitants) to } \\
64.5 \% \text { (> } 200 \text { thousand inhabitants) }\end{array}$ \\
\hline $\begin{array}{l}\text { Training } \\
\text { courses }\end{array}$ & $\begin{array}{l}67.6 \% \text { have taken courses } \\
\text { either focused on the position, } \\
\text { in public health (39.7\%) or } \\
\text { planning }(25.6 \%) \text {. }\end{array}$ & Increase (+8\%) & & $N(56.3 \%)$ & $\begin{array}{l}\text { Increases with city size: } \\
57.9 \% \text { (0-5 thousand inhabitants) to } \\
84.8 \% \text { ( } 50-200 \text { thousand inhabitants) and } \\
79.7 \% \text { (> 200thousand inhabitants ) }\end{array}$ \\
\hline
\end{tabular}




\begin{tabular}{|c|c|c|c|c|c|}
\hline $\begin{array}{l}\text { Prior experi- } \\
\text { ence in health- } \\
\text { care }\end{array}$ & $\begin{array}{l}73.8 \% \text { have prior experi- } \\
\text { ence in healthcare }\end{array}$ & Reduction (-5.2\%) & MW (79.1\%) & $S(68.5 \%)$ & $\begin{array}{l}\text { Increases with city size: } \\
67.2 \% \text { (0-5 thousand inhabitants) to } \\
89 \% \text { (> } 200 \text { thousand inhabitants) }\end{array}$ \\
\hline $\begin{array}{l}\text { Experiencing } \\
\text { managing a } \\
\text { public agency }\end{array}$ & $\begin{array}{l}64.6 \% \text { have already man- } \\
\text { aged a public agency ( } 37 . \% \\
\text { only in the healthcare area) }\end{array}$ & $\begin{array}{l}\text { Increase }(+8.3 \% \text { in } \\
\text { general, }+2.6 \% \text { in } \\
\text { healthcare })\end{array}$ & $\begin{array}{l}\text { Public AGENCY } \\
\text { N (78.4\%) } \\
\text { Healthcare area } \\
\text { NE }(44.6 \%)\end{array}$ & $\begin{array}{l}\text { Public Agency } \\
\text { SE (59.3\%) } \\
\text { Healthcare } \\
\text { area S (28.8\%) }\end{array}$ & $\begin{array}{l}\text { Increases with city size: } \\
46.4 \% \text { ( } 0-5 \text { thousand inhabitants) to } \\
92.9 \% \text { (> } 200 \text { thousand inhabitants) }\end{array}$ \\
\hline $\begin{array}{l}\text { Prior experi- } \\
\text { ence as a mu- } \\
\text { nicipal health } \\
\text { secretary }\end{array}$ & $\begin{array}{l}23.6 \% \text { had already held } \\
\text { the position of health } \\
\text { secretary, sometime in } \\
\text { the past }\end{array}$ & Increase (+7.3\%) & \multicolumn{2}{|c|}{ No significant regional differences } & $\begin{array}{l}\text { Increases with city size: } \\
17.2 \% \text { (0-5 thousand inhabitants) to } \\
30.0 \% \text { ( } 50-200 \text { thousand inhabitants) and } \\
28.3 \% \text { (> } 200 \text { thousand inhabitants) }\end{array}$ \\
\hline $\begin{array}{l}\text { Prior area of } \\
\text { work }\end{array}$ & $\begin{array}{l}67.2 \% \text { were already em- } \\
\text { ployed in the public sector }\end{array}$ & $\begin{array}{l}\text { Slight reduction } \\
(-0.5 \%)\end{array}$ & $\begin{array}{l}N(77.4 \%) \text { and } \\
\text { NE (76.7\%) }\end{array}$ & $S(59.3 \%)$ & $\begin{array}{l}\text { Increases with city size: } \\
63.4 \% \text { ( } 0-5 \text { thousand inhabitants) to } \\
77.2 \% \text { (> } 200 \text { thousand inhabitants) }\end{array}$ \\
\hline $\begin{array}{l}\text { Activities out- } \\
\text { side the health } \\
\text { department }\end{array}$ & $\begin{array}{l}44.2 \% \text { work additional } \\
\text { to their job in the health } \\
\text { department }\end{array}$ & No data for 1996 & MW (56\%) & $\begin{array}{l}N(32.5 \%) \text { and } \\
\text { S (34.6\%) }\end{array}$ & $\begin{array}{l}\text { Increases with size: } \\
34.4 \% \text { ( } 0-5 \text { thousand inhabitants) to } \\
59.6 \% \text { (> } 200 \text { thousand inhabitants) }\end{array}$ \\
\hline
\end{tabular}

Source: Own elaboration.

MW = Midwestern, $\mathrm{N}=$ North, $\mathrm{NE}=$ Northeast, $\mathrm{S}=$ South, $\mathrm{SE}=$ Southeast

Mostly, as shown in chart 3, they are firsttime occupants of the position and have previous experience in healthcare, having held prior managerial positions particularly in healthcare, and are civil servants working full-time as municipal health secretaries. The standard used for recruiting local managers suffered some significant changes between 1996 and 2006: the number of managers who are not MDs decreased while there was an increase in those specifically trained for the position and with previous managerial experience.

The profile of local SUS managers shows a multi-disciplinary makeup and professionalization of the position, as well as an increase in career civil servants who are quite familiar with public administration and healthcare management. Career development starts with professional immersion in healthcare units, followed by acquiring management experience before moving on to the position of municipal health secretary.

In addition, we find the demands of the position have increased, as most of the municipal health secretaries are full-time. Decentralization made the position of municipal health secretary more complex, with a larger number of policies and programs, and diversified rules for receiving and using federal funds, as well as the intricate volume of information to be managed. Turnover is significant since few municipal health secretaries hold the position for a second term.

Complex systems demand a manager with more extensive professional experience in the area with specific skills to perform the tasks required of the role. These changes in the decentralization process also favor the development of those with training in the humanities and management, expanding the multi-professional character of this position. This new professional profile differs from the conservative standard by providing more democratic access to the position, and from the inefficient standard, as enabling access to different social groups and professionals demands more rigorous qualification and dedication to the position. The search for specific management training is quite significant, especially in mid-sized cities of 50,000 to 200,000 inhabitants. This can be explained both by the complexity of the systems involved and the supply of courses available. 
The trend towards a new professional profile of the local SUS management elite shows significant differences by region and size of city. Particularly, in the North, one of the nation's poorest regions, we found a smaller percentage of municipal health secretaries with a university degree or courses focused specifically on the job, but more managers with prior experience in public administration, and more career civil servants working full time for the health departments. Probably because lower income and development levels offer fewer opportunities of professional market insertion, making the career of civil servant an attractive option for building a career. In the South, there are more secretaries with training in diverse areas who have not held prior management positions in healthcare, coming from outside the public sector but also highly dedicated to the position. Time dedication to the position appears to be related to the opportunities available in the broader private sector, but other factors may also be involved. The size of the healthcare system influences all of the professional attributes of local managers, as all of the variables analyzed are affected by population size.

\section{Political trajectory and public life: political/ electoral and associative experience}

Engagement in political party and health politics, and involvement in associations are important elements for recruiting the municipal health secretaries. Significant political/ party involvement mean they have influence on local party elites but not they are professional politicians. They achieved their position through a technical and administrative career. However, significant engagement in associations and political activities strictly linked to the health sector brings with it less involvement of these managers in civil society entities such as professional, community and religious associations.

\section{Political/electoral experience}

As shown in chart 4, more than half (60.4\%) of the municipal health secretaries are affiliated with a political party, showing significant engagement. However, we call attention to the fact that almost $40 \%$ are not, meaning that party affiliation is not required to be appointed to the position. Among those who do belong to a political party, most of them joined recently and are young militants: $65.9 \%$ joined the party less than 10 years ago, and $41.1 \%$ less than 5 years ago. Therefore, the position of municipal health secretaries seems to be more attractive for young technicians who are rising in their careers not appealing for those seeking more significant political positions (only $25.2 \%$ of the of municipal health secretaries had previously been candidates to public office and of the current health secretaries only $5.6 \%$ are on leave from an electoral position). 
Chart 4. Summary of the information on municipal health secretaries experience in political/ electoral experience, health politics and in civil Associations, $1996 / 2006$

\begin{tabular}{|c|c|c|c|c|c|c|}
\hline \multirow[t]{2}{*}{ Attribute } & \multirow[t]{2}{*}{ Variable } & \multirow[t]{2}{*}{ Trend (2006) } & \multirow{2}{*}{$\begin{array}{l}\text { Nationwide } \\
\text { variation, } \\
\text { 1996/2006 }\end{array}$} & \multicolumn{3}{|c|}{ Variation by region and size (2006) } \\
\hline & & & & Region & & Size \\
\hline \multirow[t]{5}{*}{$\begin{array}{l}\text { Political/ } \\
\text { Electoral } \\
\text { experi- } \\
\text { ence }\end{array}$} & $\begin{array}{l}\text { Currently affili- } \\
\text { ated to a politi- } \\
\text { cal party }\end{array}$ & $\begin{array}{l}60.4 \% \text { are affili- } \\
\text { ated to a political } \\
\text { party }\end{array}$ & $\begin{array}{l}\text { Slight reduction } \\
(-1.9 \%)\end{array}$ & $\begin{array}{l}\text { MORE } \\
\text { MW (78.9\%) }\end{array}$ & $\begin{array}{l}\text { LESS } \\
\text { SE (52.1\%) }\end{array}$ & $\begin{array}{l}\text { Not related to city size: } \\
\text { More affiliated: } 0-5 \text { thousand inhabitants } \\
\text { (68.4\%); } \\
\text { Less affiliated: } 20-50 \text { thousand inhabitants } \\
(49.9)\end{array}$ \\
\hline & Time with party & $\begin{array}{l}65.9 \% \text { have been } \\
\text { affiliated tor } 10 \\
\text { years or less, and } \\
41.1 \% \text { for } 5 \text { years } \\
\text { or less }\end{array}$ & No data for 1996 & $\begin{array}{l}\text { N }(83 \%) \text { and } \\
\text { MW }(76.5 \%)\end{array}$ & $S(60.2 \%)$ & $\begin{array}{l}\text { Party member of } 10 \text { years or less decreases } \\
\text { with city size: } \\
71.2 \% \text { ( } 0 \text { - } 5 \text { thousand inhabitants) to } 62.1 \% \\
\text { (> } 200 \text { thousand inhabitants) }\end{array}$ \\
\hline & $\begin{array}{l}\text { Running for } \\
\text { Electoral office }\end{array}$ & $\begin{array}{l}25.2 \% \text { have run for } \\
\text { public office }\end{array}$ & No data for 1996 & $\begin{array}{l}\text { No significant } r \\
\text { ferences }\end{array}$ & egional dif- & $\begin{array}{l}\text { Not related to city size: } \\
31.8 \% \text { ( } 0-5 \text { thousand inhabitants) }\end{array}$ \\
\hline & $\begin{array}{l}\text { Prior experience } \\
\text { as an elected } \\
\text { politician }\end{array}$ & $\begin{array}{l}18.6 \% \text { had already } \\
\text { been elected to a } \\
\text { political position }\end{array}$ & $\begin{array}{l}\text { Slight increase } \\
(+2.9)\end{array}$ & N (25.7\%) & SE (14.1\%) & $\begin{array}{l}\text { Decreases with city size: } \\
23.2 \% \text { (0-5 thousand inhabitants) to } 13.3 \% \\
\text { (> } 200 \text { thousand inhabitants) }\end{array}$ \\
\hline & $\begin{array}{l}\text { On leave from } \\
\text { elected office }\end{array}$ & $\begin{array}{l}5.6 \% \text { are on leave } \\
\text { from their political } \\
\text { office }\end{array}$ & No data for 1996 & N (11.1\%) & MW (1.3\%) & $\begin{array}{l}\text { Drops slightly with size of city: } \\
6.6 \% \text { ( } 0-5 \text { thousand inhabitants) to } 3.0 \% \\
\text { (> } 50 \text { thousand inhabitants) }\end{array}$ \\
\hline \multirow[t]{2}{*}{$\begin{array}{l}\text { Experi- } \\
\text { ence in } \\
\text { health } \\
\text { politics }\end{array}$} & $\begin{array}{l}\text { Participation in } \\
\text { events }\end{array}$ & $\begin{array}{l}98 \% \text { have already } \\
\text { participated in } \\
\text { some political } \\
\text { healthcare event }\end{array}$ & $\begin{array}{l}\text { Slight increase } \\
(+3.9 \%)\end{array}$ & No significant c & hange & No significant change \\
\hline & $\begin{array}{l}\text { Involvement } \\
\text { in entities and } \\
\text { forums }\end{array}$ & $\begin{array}{l}68.9 \% \text { have } \\
\text { been involved in } \\
\text { COSEMS } 59.2 \% \\
\text { have been involved } \\
\text { in RBIC }\end{array}$ & No data for 1996 & $\begin{array}{l}\text { RBIC N } \\
(83.4 \%) \\
\text { COSEMS N } \\
(89.1 \%)\end{array}$ & $\begin{array}{l}\text { COSEMS SE } \\
(60.1 \%)\end{array}$ & $\begin{array}{l}\text { Increases with city size: } \\
\text { COSEMS } /-7.7 \% \text { ( } 0-5 \text { thousand inhabit- } \\
\text { ants) to }+13.8 \% \text { ( }>50 \text { thousand inhabit- } \\
\text { ants) } \\
\text { RBIC/-9\% ( } 0-5 \text { thousand inhabitants) to } \\
+15.7 \% \text { (> } 50 \text { thousand inhabitants) }\end{array}$ \\
\hline \multirow[t]{3}{*}{$\begin{array}{l}\text { Experi- } \\
\text { ence in } \\
\text { associa- } \\
\text { tions }\end{array}$} & $\begin{array}{l}\text { Membership in } \\
\text { civil societies }\end{array}$ & $\begin{array}{l}67.8 \% \text { belong or } \\
\text { have belonged to } \\
\text { civil society asso- } \\
\text { ciations. }\end{array}$ & $\begin{array}{l}\text { Very significant } \\
\text { reduction }(-16.2 \%)\end{array}$ & $\mathrm{S}(78.8 \%)$ & SE (63\%) & $\begin{array}{l}\text { Higher rate of membership in cities of }>50 \\
\text { thousand inhabitants }\end{array}$ \\
\hline & $\begin{array}{l}\text { Types of asso- } \\
\text { ciations }\end{array}$ & $\begin{array}{l}\text { Professional } \\
\text { associations } \\
(25.6 \%) \text {, religious } \\
\text { associations } \\
(22.5 \%) \text {, social } \\
\text { clubs }(19.8 \%) \text { and } \\
\text { unions }(16.2 \%)\end{array}$ & $\begin{array}{l}\text { Social clubs } \\
(-21.8 \%) \text { Profes- } \\
\text { sional associations } \\
(-18.1 \%)\end{array}$ & $\begin{array}{l}\text { Social clubs } \\
\text { S (35.7\%) } \\
\text { Religious as- } \\
\text { sociations } \\
\text { S (32\%) } \\
\text { Professional } \\
\text { associations } \\
\text { MW (34.9\%) }\end{array}$ & $\begin{array}{l}\text { Social clubs } \\
\mathrm{N}(6.9 \%), \\
\mathrm{NE}(12.4 \%) \\
\text { and } \mathrm{MW} \\
(12.1 \%) \\
\text { Religious } \\
\text { associations } \\
\text { NE (14\%) }\end{array}$ & $\begin{array}{l}\text { Increases with city size: } \\
\text { Professional associations ( } 18.2 \% / 0-5 \text { thou- } \\
\text { sand to } 66 \% />200 \text { thousand) and service } \\
\text { clubs ( } 9.6 \% / 0-5 \text { thousand to } 25.1 \% />200 \\
\text { thousand). } \\
\text { Goes down with city size: } \\
\text { Community associations ( } 12.3 \% / 0-5 \text { thou- } \\
\text { sand to } 4 \% />200 \text { thousand); religious as- } \\
\text { sociations ( } 33.1 \% / 0-5 \text { thousand to } 15.8 \%> \\
200 \text { thousand). }\end{array}$ \\
\hline & $\begin{array}{l}\text { Importance } \\
\text { assigned by } \\
\text { manager }\end{array}$ & $\begin{array}{l}30.4 \% \text { assign high } \\
\text { importance }\end{array}$ & No data for 1996 & MW (41.6\%) & $\begin{array}{l}\text { NE }(23.5 \%) \\
\text { and N } \\
(24.2 \%)\end{array}$ & No significant change \\
\hline
\end{tabular}

Source: Own elaboration.

Cosems = Council of Municipal Health Secretariats of Minas Gerais, MW = Midwetern, N = North, NE = Northeast, RBIC = Regional Bipartisan Inter-managers Committees, $\mathrm{S}=$ South, SE = Southeast. 
However, more than two-thirds of the managers who do run for elective office (18.6\%) won the elections, showing the position gave them significant visibility in the local political scene.

Size of city seems to influence the length of time of party affiliation. The larger the city, the bigger the number of municipal health secretaries affiliated for over 10 years, but fewer who have held previous elected positions. Therefore, the municipal health secretaries participate in party life, although the growing demand for technical qualification to perform the function results in managers who are not professional politicians and are not seeking electoral office.

\section{Engagement in health politics}

As shown in chart 4, Engagement in sector politics is a more important expression of political activity among municipal health secretaries, and has remained significant throughout the decentralization process. This shows that even after achieving increased managerial autonomy in the 1990s, sector mobilization remains significant. Almost all managers (98\%) have participated in some political event in the healthcare sector. $86.1 \%$ have been to regional Municipal Health Secretariat meetings, 67.3\% have been to city health conferences, $44.1 \%$ to National Health Secretariat meetings and $44.3 \%$ to state health conferences.

We call attention to the fact that participation in health regional events is larger than in city events, even though both are required under SUS regulations. Preference for peer meetings suggests managers are migrating from political activity to the healthcare management agenda. We found high levels of participation in entities of health managers, and inter-management forums. 68.9\% had already been involved in regional associations of municipal health secretaries (Cosems), and $59.1 \%$ in RBIC in their state.

It is important to note that while involvement in political events does not vary with size of city, participation in inter-management negotiation forums in different spheres of government and in corporate entities happens far more in larger cities. Thus, suggesting that there is a hierarchy in the access to power in these instances, where the size of the local healthcare systems exerts a significant influence.

\section{Involvement in associations}

While political mobilization for sector activities increased with decentralization, the engagement of municipal health secretaries in civil society organizations declined quite significantly in the period analyzed, although still rather high, as over two-thirds (67.8\%) remain involved in some way with civil society associations. There is a high level of involvement in local community institutions but it is dropping.

The range of entities in which municipal health secretaries participate is quite broad, and includes particularly professional associations (25.6\%), religious associations (22.5\%), social and sports clubs (19.8\%), unions (16.2\%), service clubs (12.9\%), community associations (11\%) and other associations (11.5\%). It is interesting to note that the nature of their involvement is influenced by city population. Engagement in professional associations and service clubs is more common in the larger cities, while engagement in community and religious associations is more common in the smaller cities.

Between 1996 and 2006, municipal health secretaries involvement in associations dropped by about one-sixth nation-wide (16.2\%), in particular in social clubs (-21.8\%) and professional associations (-18.1\%). This drop is in contract to the involvement of municipal health secretaries in healthcare meetings and managers entities, which remains at a high level. This may be an effect of the SUS institutionalization process, whose challenges demand increasing amounts of attention from managers. This change is reflected in the importance managers assign to engagement in civil society association. Only $30.4 \%$ believe this to be very important, with higher levels found in the less developed regions.

Fenwick and Bailey ${ }^{31}$ designated as new corporatism the tendency towards pursuing 
strategic aims through new structures of corporate management. Endogenous engagement however, may represent the risk of losing consistent bonds between managers and organized civil society, isolating sector management in an insular technical universe.

\section{Perceptions regarding the position of secretary}

Decentralization has made the position more stable, and mayors have tried to appoint managers who combine political commitment and technical and managerial skills. From the point of view of the municipal health sercretaries themselves, the SUS has increasingly represented an opportunity for professional growth.

Most (63.5\%) health secretaries have held this position since the start of the previous or current administration, and claim to have been appointed primarily based on: personal trust (78.5\%), leadership skills (54.5\%), administrative experience (42.8\%), and technical experience (36.5\%). They accepted the position in order to be of service to their community ( $87.2 \%)$, have a commitment in healthcare (85.9\%), embrace a challenge (74.8\%), or accumulate professional experience (61.2\%). Mostly, $60.1 \%$, plan to remain working in the public area.

Some of these characteristics became stronger in the decade between 1996 and 2006. Over this period, there was a significant increase in the number of managers appointed due to their leadership skills (32.1\% to 54.5\%) and personal trust (64.5\% to $78.5 \%)$. The number of managers who accepted the position to embrace new challenges raised form $47.3 \%$ to $74.8 \%$ and higher to improve their resumes from $15.7 \%$ to $46.9 \%$. These results show increased stability in this job, which has become increasingly attractive.

\section{Conclusions}

In general, decentralization expanded access of diverse population groups to healthcare management, and increased professionalization of the position of municipal health secretary. On the one hand, creating an organized national healthcare system with local platforms to provide services, and areas for involvement of civil society, resulted in a legal governance model that is more permeable to diversified participation. On the other hand, the constant challenges of implementing a broad set of healthcare units and programs to ensure universal access, as well as creating the corresponding administrative and financial structures call for recruiting and training managers that are better qualified and skilled for the position.

A larger number of women, Afrodescendants and brown in the position of manager show the strength and continuity of the process underway to expand access to the position, departing from the conservative recruiting standard that perpetuated the local elites in power. Easier access is also further from a standard of inclusive, yet inefficient management, showing that renewing the local elites came together with an increase in their professional qualification for the position. The governance of diversity is one of the new challenges for health system.

A major challenge to overcome is the resilience of larger cities to more democratic access by the various social groups. Unlike what we expected, in the larger cities and more developed regions competition for this position has led to the predominance of a standard of recruiting we have labelled elitist, as it combines high levels of professionalism with restrictions to access by diversified groups. Therefore, where there is more competition and concentration of power the standard of recruitment with major requirements excludes the less favored social groups, reproducing an elitist model in the exercise of power.

Another challenge to be faced has to do with the relationship between the technical and political sides of the position. With the increase in complexity, managers tend to increase their involvement in peer entities and associations, distancing them from a political practice with closer ties to parties and 
organized civil society. If on the one side this suggests that the function is becoming increasingly professional, on the other it increases the endogenic feature of health sector politics. This trend may compromise the desired intersectorial management of public policies, as well as manager ability to combine technical requirements and political action, essential to strengthen democratic governance bases.

Considering the importance of local authorities to accomplish the four societal functions in Stoker's typology ${ }^{22}$, our results show the diversification of managers' profile as a way to express and build local identity and the increasing professionalism as a requirement for better welfare provision. Both features can improve legitimacy of local power exercise. However, the tendency to detach this practice from the network of civil society organizations and isolate public management inside corporatists groups can undermine legitimacy and reduce the possibilities to realize thoroughly the important social functions of promoting economic development and place shaping.

Policies to promote diversity must come with professional training tools and political measures to rearticulate managers and stakeholders in local associations, given the need to close persistent regional and city size gaps.

\section{Contributors}

Fleury S and Ouverney ALM contributed to the conduct of research, data collection and processing, and article analysis and writing. 


\section{References}

1. Tocqueville A. A democracia na América. São Paulo: Edusp; 1977.

2. Putnam RD. Making democracy work: civil traditions in modern Italy. Princeton: Princeton University Press; 1993.

3. Andrew C, Goldsmith M. From local government to local governance: and beyond? Inter. Polit. Science Rev. 1998; 19(2):101-117.

4. Dahl R. The science of public administration: three problems. Public Adm Rev. 1947; 7(1):1-11.

5. Finer H. Administrative responsibility in democratic government. Public Adm Rev 1941; 1(4):335-350.

6. Kirlin J. The big questions of public administration in a democracy. Public Adm Rev. 1996; 56:416-423.

7. Stoker G. Governance as theory: five propositions. Int Soc Sci J. 1998; 50:17-28.

8. Stoker G. Public value management: a new narrative for networked governance? The American Review of Public Administration. 1998; 36:41-57.

9. Lechner N. Three forms of social coordination. CEPAL Rev. 1997; 61:7-17.

10. Shah A, Sana S. The new vision of local governance and evolving roles of local governments. In: Shah A, editor. Local governance in developing countries. Washington, DC: The World Bank; 2006. p. 1-46.

11. Rhodes R. Understanding governance: policy networks, governance, reflexivity, and accountability. Buckingham: Open University Press; 1997.

12. Pires R. Efetividade das instituições participativas no Brasil: estratégias de avaliação. Brasília: IPEA; 2011. v. 7.

13. Levicovitz E, Lima LD, Machado CV. A política de saúde nos anos 1990: relações intergovernamentais e o papel das normas operacionais básicas. Ciênc. Saúde Colet. 2001; 6(2):269-291.

14. Santos L, Andrade OM. O espaço da gestão inovadora e dos consensos interfederativos: aspectos jurídicos, administrativos e financeiros. Campinas: Instituto de Direito Sanitário; 2007.

15. Arretche M, Marques E. Municipalização da saúde no Brasil: diferenças regionais, poder do voto e estratégias de governo. Ciênc. Saúde Colet. 2002; 7(3):455479.

16. Arretche M. A política da política de saúde no Brasil. In: Lima NT, Gerschman S, Edler FC, et al, organizadores. Saúde e democracia: histórias e perspectivas do SUS. Rio de Janeiro: Fiocruz; 2005. p. 285-306.

17. Marques RM, Mendes A. A política de incentivos do Ministério da Saúde para a atenção básica: uma ameaça à autonomia dos gestores municipais e ao princípio da integralidade? Cad. Saúde Pública. 2002; 18(supl):163-171.

18. Moreira MR, Escorel S. Conselhos Municipais de Saúde no Brasil: um debate sobre a democratização da política de saúde nos vinte anos do SUS. Ciênc. Saúde Colet. 2009; 14(3):795-806.

19. Ribeiro JM. Conselhos de saúde, comissões intergestores e grupos de interesses no Sistema Único de Saúde (SUS). Cad. Saúde Pública. 1997; 13(1):81-92.

20. Afonso MVG, Oliveira IA. Apresentação dos resultados das Pesquisas Perfil das CIR e Perfil dos Gestores. Relatoria de Seminário. In: Anais $34^{\circ}$ Congresso Nacional de Secretarias Municipais de Saúde [internet]; 2018 June 25; Belém. Pará: Conasems. [accessed in 2018 Aug 28]. Avaiable in: www.nesp.unb.br/ forum/download/file.php?id=333\&sid.

21. Ouverney AM. A construção da municipalização da saúde: estratégias normativas. In: Fleury S, organizer. Democracia e inovação na gestão local da saúde. Rio de Janeiro: CEBES; Fiocruz; 2014. p. 81-120. 
22. Fleury S. Universal, dual or plural? health care models and issues in latin america. In: Molina C, Arco $\mathrm{J}$, editors. Health services in Latin America and Asia. Washington, DC: Inter-American Development Bank; 2001. p. 2-36.

23. Grant B, Dollery B. The contribution of Gerry Stoker to the theory and practice of local government reform: a critical overview. Armidale: Centre for Local Government, School of Economics; 2011.

24. Streib G. Revisiting the case for professionalizing public administration. Atlanta: Andrew Young School of Policy Studies; 2009.

25. Fleury S. Democracia, poder local y ciudadania en Brasil. In: Gomá R, Jordana J, editors. Descentralización y políticas sociales en América Latina. Barcelona: Fundación CIDOB; 2004. p. 243-268.

26. Brasil. Lei ${ }^{\circ} 12.466$ de 24 de Agosto de 2011. Acrescenta arts. 14-A e 14-B à Lei no 8.080, de 19 de setembro de 1990, que "dispõe sobre as condições para a promoção, proteção e recuperação da saúde, a organização e o funcionamento dos serviços correspondentes e dá outras providências", para dispor sobre as comissões intergestores do Sistema Único de Saúde (SUS), o Conselho Nacional de Secretários de Saúde (Conass), o Conselho Nacional de Secretarias Municipais de Saúde (Conasems) e suas respectivas composições, e dar outras providências. Diário Oficial da União. 25 Aug 2011.

27. Fleury S, Ouverney AM, Moller R. Democratização do Poder Local e as Dimensões da Inovação em Saúde. In: Fleury S, organizer. Democracia e inovação na gestão local da saúde. Rio de Janeiro: Cebes; Fiocruz; 2014. p. 121-198.

28. Fenwick J, Bailey M. Local government reorganisation in the UK: decentralisation or corporatism? Inter. Journal of Public Sector Management. 1999; 12(3):249-261.

29. Instituto Brasileiro de Geografia e Estatística IBGE. Perfil dos municípios brasileiros. Rio de Janeiro: IBGE; 2017.

30. Waiselfisz JJ, Silva RNP. Dirigentes Muncipais da Educação: Um Perfil. Brasília, DF: UNESCO; UNDIME; Fundação Ford; 2000.

31. Silva TD, Silva JM. Reserva de vagas para negros em concursos públicos: uma análise a partir do Projeto de Lei n ${ }^{\circ}$ 6.738/2013. Brasília, DF: IPEA; 2014.

\footnotetext{
Received on $04 / 26 / 2018$

Approved on 09/10/2018

Conflict of interests: non-existent

Financial support: non-existent
} 